\title{
Assuring food security in Singapore, a small island state facing COVID-19
}

\author{
Paul Teng ${ }^{1}$ \\ Received: 6 May 2020 / Accepted: 30 June 2020 / Published online: 7 July 2020 \\ (C) International Society for Plant Pathology and Springer Nature B.V. 2020
}

\begin{abstract}
Small island states have features in common which make it difficult for them to assure food security through self-production, notably limited land, fresh water and labour. As these island states grow economically, diet diversification by an increasingly affluent population demands a balance between food imports and self-production. Singapore, a wealthy, small island state has consistently been ranked high in food security in international comparisons, but only under conditions when trade is uninhibited and countries do not reduce food exports. The COVID-19 pandemic has shown vulnerabilities in the country's "Resilience" strategy to maintain food security through importing over $90 \%$ of its food needs from over 170 countries. Leading up to and during the pandemic, strategic policy initiatives were announced by the government and new measures were taken to increase the stability of imports, ramp up production from existing farms, increase self-production by $300 \%$ by 2030 through increasing the number of high technology urban vegetable and fish farms, and factory-cultured food, and reducing food waste. Singapore offers lessons for other small island states in ways to improve their food security.
\end{abstract}

Keywords Food security $\cdot$ COVID-19 $\cdot$ Small island state $\cdot$ Singapore

\section{Introduction}

Because of their geographic limitations, small island states have features which differentiate their food security concerns from those of larger countries with much natural resources of land and water to support agriculture. One such feature is reliance on imported food, especially staples (like rice or wheat) and animal protein. As such, small island states are particularly vulnerable to disruptions in the supply chains of all imported food. Singapore, as a small island state of about $800 \mathrm{~km}^{2}$ is reported by its Singapore Food Agency to have imported $90 \%$ of its food needs in 2019 from over 170 countries, geographically spread (Singapore Food Agency 2020). The island has also performed well in international comparisons such as the Global Food Security Index (GFSI) published annually by the Economist

Paul Teng

paul.teng@nie.edu.sg

1 Centre for Non-Traditional Security (NTS) Studies, S. Rajaratnam School of International Studies, Nanyang Technological University, 1 Nanyang Walk, Singapore 637616, Singapore
Intelligence Unit, U.K. (The Economist Intelligence Unit 2019). In 2019 it was ranked the most food secure country out of 113. Singapore therefore offers a case study on the policies, capabilities and technologies that contribute to assuring food security in a small island state, in non-crisis situations and when challenged by a pandemic crisis.

\section{Foundations to achieve a high level of food security}

The GFSI rank given to Singapore was based on a multirubric scoring system that adopted the 1996 World Food Summit definition for Food Security - that it "exists when all people, at all times, have physical, social and economic access to sufficient, safe and nutritious food that meets their dietary needs and food preferences for an active and healthy life" (Food and Agriculture Organization, United Nations 2009). Singapore scored high on the rubrics concerning availability, affordability, quality and safety, but low on natural resources and resilience. 


\subsection{Food availability and physical access to food}

As with other small island states, food availability is made possible through limited self-production of some food items, importation of most food and stockpiles. Self-production is done mainly in surrounding coastal waters (for fish) and in six agro-technology parks which collectively comprise about $1.8 \%$ of total land area (used to produce fish, vegetables, eggs and miscellaneous minor items like quails and frogs). As of 2019, there were 77 vegetable farms, 3 egg farms and 122 fish farms. These farms met, respectively $14 \%, 10 \%$ and $26 \%$ of the island's needs of vegetables, fish and eggs, for a population of 5.7 million (Singapore Food Agency 2000). Singapore, like most middle to high income island states, applied an approach which the Food and Agriculture Organization, United Nations (FAO,UN) called "self-reliance", in which some level of domestic food production is maintained and the capacity is generated to import from the world market as needed (Konandreas 2000). There is no explicit goal to achieve $100 \%$ food self-sufficiency.

The second approach to make food available is what Singapore calls its "Resilience" strategy for food import sourcing. This strategy is implemented by importing from a geographically diverse group of countries for each food item. For example, chicken is imported mainly from Brazil, Malaysia, U.S.A. and Argentina while vegetables from Malaysia, China, India and Australia (Singapore Food Agency 2000). The government's food agency routinely sends out "scouting" teams around the world to develop new sources and supply chains. Stockpiles are the third approach used by most countries to ensure availability of key food items during periods of scarcity and a recent study by the Southeast Asian Center for Graduate Studies and Research in Agriculture (SEARCA) showed that every one of the ten countries in ASEAN had stockpiles of, minimally, rice (Teng and Darvin 2019).

\subsection{Economic access to food}

The affordability of food, as another important dimension of food security, depends on the price of food and the purchasing power of citizens. A policy of zero tariff on food and efficient logistics to handle food are two factors which help prevent the need to raise prices. Empowering its citizens with purchasing power adds to the favorable economic access to food. The average Singapore household has a relatively high Gross Domestic Product (GDP) per household, and with zero tariffs on food, this makes food expenditures a relatively small part of household budgets; by government statistics, less than $10 \%$. This compares well with neighbouring countries in which household expenditures on food are in the range of $30-45 \%$ of household incomes (Our World in Data 2020). It may be argued that economically less developed island states may not have the same capacity to import and provide food with affordable access to most of their citizens because of lower GDP per household.

\subsection{Food utilization}

Another foundational reason for Singapore's high GFSI ranking is with respect to the next dimension of food security food quality and safety. It is generally recognized in the Southeast Asian region that the country has one of the strictest and most robust systems to assure food safety, whether it is chemical or biological. Additionally, food handling regulations stipulate procedures to maintain the nutritive value of fresh produce.

As with other small island states, Singapore lacks the natural resources and ecological resiliency in its agriculture base. But the country has attempted to counter this by focusing on space-limited, technology-enabled urban farming which currently provides about $10 \%$ of its needs (Singapore Food Agency 2020).

\section{Effect of COVID-19 on food security}

COVID-19 has generally disrupted food supply chains and consequently, also impacted on the different dimensions of food security. Apart from COVID-19, small island states are particularly vulnerable to other disruptors which reduce the quantum of food available for export from source countries, like severe weather events, natural disasters, and pest and disease outbreaks.

Experience from the 2007-08 food crisis has shown that unexpected agricultural production shocks lead to panic reactions by governments to restrict food exports and accumulate domestic stocks, thereby precipitating a chain of events leading to temporary food shortages, price spikes, price gouging and food hoarding by consumers. These have all been seen in the first months of the current pandemic in different countries (Hossain 2020). The International Food Policy Research Institute (IFPRI) using data from FAO, UN and its own models, have both projected that there are ample food stocks for 2020 and there is no justification for export restrictions (Vos et al. 2020). Both food availability and economic access to food have been affected by hasty reactions to the perceived threat of reduced food stocks.

One common intervention measure adopted by many countries, including small island states, to reduce virus spread has been movement control or "lockdowns". Epidemiologically this is justifiable but as has been seen, the indirect effects have been to reduce farmer ability to harvest and transport their produce to markets, delay planting of crops, prevent agricultural inputs getting to farmers and delaying food retailers like supermarkets from receiving replenishments (Hossain 2020). 
Transport capacity of food from exporting to importing small island states like those in the South Pacific via sea and air have also been drastically reduced, reducing the physical access to food (Teng 2020).

"Lockdowns" have further had the unexpected effect of depriving millions of daily-waged workers of their ability to purchase food in many Asian countries. While still not obvious it is anticipated that there will be increased hunger and malnutrition in many developing countries (Hossain 2020).

\section{Developing enduring solutions?}

Small island states face the reality that, as their populations increase and their economic status improve, there is a need to import a more diverse basket of food and possibly higher quantums. Economists have long argued that countries that are land and fresh water limited do not have the comparative advantage to have high levels of food self-production, especially with respect to "extensive crops" such as rice and wheat. The alternative is to focus on producing food items which do not require much land, water or labour.

Small island states with developing economies face the dilemma of growing enough food for sustenance versus using the limited land and water to engage in higher value economic activities with export potential (e.g. light industries) or potential to earn foreign exchange domestically (e.g. tourism). Examples are many of the countries in the Caribbean and South Pacific. Exiting this dilemma appears to require foreign direct investment coupled with development plans supported by transparent governance.

Singapore offers some lessons of deriving enduring solutions to assure food security with economic growth and a systematic plan to have a food buffer for short periods of supply shortages (Caballero- Anthony et al. 2020). Starting in the mid twentieth Century, agriculture gradually declined in its contribution to national GDP and during the 1980s, a policy decision was made to limit all farming to about $1 \%$ of land area and to shift focus to economic activities with higher land and labor productivity such as service industries and manufacturing. This has enabled the island to have one of the highest GDP per capita in the world. However, food supply disruptions and price hikes during the 2007-08 crisis and subsequently, led to the government revisiting the role of agriculture to provide a buffer against such disruptions. Efforts culminated in the launch in March 2019 of an ambitious programme to increase nutrition self-sufficiency to $30 \%$ (from $10 \%$ ) by 2030 , commonly called the "Singapore Food Story" and also launching a new Singapore Food Agency (Teng et al. 2019). The Singapore Food Story has three focus areas - Urban agriculture and aquaculture (high technology indoor and outdoor farms), Future food (targeting alternative proteins like plant-based protein and cellular meat, etc.) and
Food science and technology, and would be the basis for innovations in farming and food processing. It taps into all the existing expertise in higher education institutes, government agencies and the private sector and is backed by an initial tranche of Singapore \$ 144 million (about US\$ 101 million). COVID-19 has further led to another Singapore \$30 million (about US\$ 21 million) being made available from April 2020 to ramp up production of vegetables, eggs and fish by local farms in the shortest time possible (Singapore Food Agency 2000). This reflects concerns about the disruption of food supply chains from measures to reduce the pandemic's progress. Increasingly too, research has been funded to Singapore universities and their overseas collaborators to improve agriculture in neighbouring countries.

As a small island state, Singapore has recognised the limits of how much it can realistically produce, even with the use of efficient technology. To sustain the imports which are responsible for the bulk of its food needs, the country in March 2020 developed binding "Supply Chain Connectivity Agreements" with five other trading partners. Concurrent with this are existing overseas food production collaboration projects which allow a portion of the production to be exported back to Singapore; an example is a $2500 \mathrm{~km}^{2}$ agri-food zone in Jilin province, China which has started exporting rice. Admittedly, not all the initiatives taken by Singapore are adoptable by other small island states. Nevertheless they provide indications of what are possible.

\section{Conclusions}

Singapore's experience with the COVID-19 pandemic has affirmed several elements of its strategy to maintain food security which offer lessons for other small island states (Caballero-Anthony et al. 2020). Overall, increasing the economic status of citizens, as measured by GDP per capita, is important to assure economic access to food. The GFSI (The Economist Intelligence Unit 2019) clearly shows the strong correlation that as GDP per capita increases, so does household food security. Nationally, this has been backed by the country's improvements in supply chain logistics and infrastructure to handle food importation and distribution with high quality food safety standards. The "Resilience" approach to food importation has proven to be a sound one, as diverse sources of imports from around the world has largely provided options to ensure food imports have alternative geographically-spread sources. Singapore has also chosen to make food security an important policy issue in national security, with the government giving priority to investments for research and development, and enterprises that strengthen the agriculture and food sectors. These investments have originated domestically and from overseas. Foreign direct investment has been encouraged largely because of the good governance, 
sound intellectual property regime and tax incentives legislated by the government. A consistent and coherent policy approach to ensuring food security in the face of disruptors like COVID-19 is one feature of the response, as also shown by many other Asian countries (Hossain 2020).

Stabilizing food security is a goal that most countries have but with small island states, it is a fine balance between supply (imports, self-production and stockpiles) and demand (consumer diets, expectations and wastage). Unlike large countries with arable land, fresh water, labour and availability of inputs, small island states are always vulnerable to external phenomena beyond their control, and have low resiliency. As Singapore has shown, what it can do is to develop solutions which assure a capacity to buffer against supply disruptions for a short period by developing internal capacity to produce currently $10 \%$ of its food needs but going up to $30 \%$ by 2030 . And concurrently, invest to develop the capacity to import from diverse sources and through policy interventions, seek binding agreements with those exporting countries willing to keep supply chains open in times of crisis.

\section{Compliance with ethical standards}

Conflicts of interest/competing interests The author declares that there is no conflict of interest

\section{References}

Caballero- Anthony, M, Teng, P \& Montesclaros, JML (2020). COVID19 and Food Security in Asia: How Prepared are We? NTS Insight, No. I, N20-03. Singapore: RSIS Centre for Non- Traditional Security Studies (NTS Centre), Nanyang Technological University Singapore. https:/www.rsis.edu.sg/wp-content/uploads/2020/06/ NTS-Insight Food-Security-Preparedness June-9-2020.pdf. Accessed 19 June 2020.

Food and Agriculture Organization, United Nations. (2009). Draft Declaration of the World Summit on Food Security, Rome, 16-18 November 2009. Document no. WSFS 2009/2. http://www.fao.org/ fileadmin/templates/wsfs/Summit/Docs/Declaration/WSFS09 Draft_Declaration.pdf. Accessed 25 April 2020.

Hossain, S. T. (2020). Impacts of COVID-19 on the Agri-food sector: Food security policies of Asian productivity organization members. The Journal of Agricultural Sciences - Sri Lanka, 15(2), 116-132. https://doi.org/10.4038/jas.v15i2.8794.

Konandreas, P. (2000). Trade and food security: Options for developing countries, in multilateral trade negotiations on agriculture: A resource manual, FAO, Rome.
Singapore Food Agency. (2000). Singapore's modern farm series. Online publication. https://www.sfa.gov.sg/food-for-thought/tags?tag= singapores-modern-farm-series\&page $=1$. (Accessed on 15 April 2020).

Singapore Food Agency. (2020). Levelling up Singapore's food supply resilience. Online publication. https://www.sfa.gov.sg/food-forthought/article/detail/levelling-up-singapore-s-food-supplyresilience (Accessed on 28 April 2020).

Teng, P. (2020). COVID-19: Maintaining food security in Asia Pacific. Opinion Editorial published by Inter Press Service News Agency, FAO, UN, Rome online on April 162020 . https://www.ipsnews.net/ 2020/04/covid-19-maintaining-food-security-asia-pacific/

Teng, P.S. \& Darvin. B.A.C. (2019). (Ed). Food reserves: A comparative study on food reserve management and policies in Southeast Asia. SEARCA College, Los Baños, Laguna, Philippines.

Teng, P., Montesclaros, J.M.L., Hulme, R. \& Powell, A. (2019). The evolving Singapore Agrifood ecosystem. NTS insight, no. IN1903, august 2019, S. Rajaratnam School of International Studies, Nanyang Technological University Singapore. https:/www.rsis. edu.sg/wp-content/uploads/2019/08/NTS-InsightTengMontesclarosHulmePowell-Aug2019.pdf. Accessed 15 May 2020.

The Economist Intelligence Unit. (2019). Global food security index. https://foodsecurityindex.eiu.com/ Accessed 15 January 2020.

Our World in Data. (2020). Determinants of food expenditure. Engel's Law. https://ourworldindata.org/food-prices. Accessed 15 April 2020.

Vos, R., Martin, W. \& Laborde, D. (2020). As COVID-19 spreads, no major concern for global food security yet. IFPRI Blog posted March 10 2020. https://www.ifpri.org/blog/covid-19-spreads-nomajor-concern-global-food-security-yet. Accessed 15 April 2020.

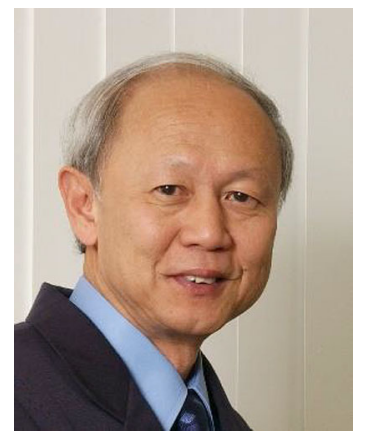

Professor Paul Teng is Managing Director, NIE International Pte. Ltd., and Adjunct Senior Fellow, Centre for Non-Traditional Security Studies, RSIS, both belonging to Nanyang Technological University, Singapore. His current interests are in food security, commercialization and biosafety of crop biotechnology, agritechnology innovations and bio-entrepreneurship, and sustainable development. He researches urban high-technology enabled farming and "plant factories". He has over thirty years of experience from positions in international organizations (the International Rice Research Institute, and the Worldfish Centre), U.S. universities (University of Minnesota, University of Hawaii) and the private sector. Prof. Teng has won numerous awards for his work such as the Eriksson Prize in Plant Pathology, an Honorary Doctor of Science from Murdoch University, Australia and is a Fellow of the American Phytopathological Society, The International Society of Plant Pathology, and The World Academy of Sciences (TWAS). 